JIPU SILABI Education Vol. V No. 4 April - Juni 2017

\title{
PENGARUH BIAYA PEMELIHARAAN AKTIVA TETAP TERHADAP LABA PADA PT. CIPTA BETONSINAR PERKASA DI KOTA MAKASSAR
}

\author{
Dahlia \\ Dosen Program Studi Akuntansi Universitas Sulawesi Barat \\ Email: dahlia@unsulbar.ac.id
}

\begin{abstract}
ABSTRAK
Dalam suatu organisasi terutama perusahaan manufaktur kegiatan pemeliharaan merupakan suatu fungsi yang sama pentingnya dengan fungsi-fungsi yang lain seperti fungsi produksi, hal ini dikarenakan peralatan atau fasilitas yang dimiliki diharapkan akan selalu dapat dipergunakan. PT. Cipta Beton Sinar Perkasa adalah salah satu perusahaan yang bergerak dalam bidang produksi campuran beton jadi, jasa kontraktor, dan developer. Perusahaan tersebut memiliki banyak aktiva tetap seperti alat-alat berat untuk produksi dan kendaraan yang memerlukan pemeliharaan yang berkesinambungan agar kondisi aktiva tetap tersebut berada dalam kondisi baik yang pada akhirnya produksi perusahaan bisa tetap berjalan dengan lancar. Penelitian ini bertujuan untuk mengetahui pengaruh biaya pemeliharaan aktiva tetap terhadap laba pada PT. Cipta Beton Sinar Perkasa di Kota Makassar. Teknik analisis data yang digunakan yaitu analisis regresi linear sederhana. Berdasarkan hasil penelitian, diperoleh hasil bahwa biaya pemeliharaan aktiva tetap berpengaruh signifikan terhadap laba pada PT. Cipta Beton Sinar Perkasa di Kota Makassar. Adapun pengaruh sangat kuat yang dimaksudkan adalah pengaruh negatif.
\end{abstract}

Kata Kunci : Biaya Pemeliharaan, Laba

\section{PENDAHULUAN}

Seiring dengan semakin majunya ilmu pengetahuan dan teknologi yang dikuasai oleh manusia dalam menyelesaikan suatu pekerjaan, menyebabkan adanya peningkatan kebutuhan manusia baik dalam jumlah, variasi dan kualitasnya. Perkembangan ini menimbulkan tantangan bagi perusahaan untuk menciptakan sekaligus mendistribusikan barang ataupun jasa guna memenuhi kebutuhan konsumen tersebut (permintaan pasar). Usaha-usaha ini dilakukan agar perusahaan dapat mencapai laba yang diharapkan dalam menjamin kelangsungan hidup perusahaan dimasa yang akan datang. Laba merupakan sesuatu hal yang penting karena jumlah laba yang diperoleh 
suatu perusahaan merupakan indikator keberhasilan usahanya.

Dalam suatu organisasi terutama perusahaan manufaktur kegiatan pemeliharaan merupakan suatu fungsi yang sama pentingnya dengan fungsi-fungsi yang lain seperti fungsi produksi. Hal ini dikarenakan peralatan atau fasilitas yang dimiliki diharapkan akan selalu dapat dipergunakan. Demikian pula dengan perusahaan manufaktur dimana pimpinan perusahaan akan selalu berusaha agar fasilitas/peralatan produksinya (aktiva tetap) dapat dipergunakan sepanjang umurnya sehingga kegiatan produksi dapat berjalan lancar. Dalam usaha untuk dapat mempergunakan terus fasilitas tersebut agar kontinuitas produksi dapat terjamin, maka dibutuhkan kegiatan-kegiatan pemeliharaan dan perawatan yang meliputi kegiatan pengecekan, perminyakan (lubrication) dan perbaikan/reparasi atas kerusakankerusakan yang ada serta penyesuaian atau penggantian komponen yang terdapat pada fasilitas tersebut. Peranan pemeliharaan tidak hanya untuk menjaga agar pabrik dapat bekerja dan produk dapat diproduksi dan diserahkan kepada pelanggan tepat pada waktunya, tetapi juga untuk menjaga agar pabrik dapat bekerja secara efisien dengan menekan atau mengurangi kemacetan-kemacetan sekecil mungkin.

Dalam suatu perusahaan sering terlihat pihak manajemen kurang memperhatikannya bidang pemeliharaan atau maintenance. Hal tersebut dapat berupa jadwal kegiatan pemeliharaan yang tidak teratur. Peran penting dari kegiatan pemeliharaan akan disadari segera setelah mesin atau aktiva tetap lainnya yang dimiliki rusak atau bahkan tidak dapat berjalan sama sekali. Padahal kegiatan pemeliharaan harus dapat menjamin bahwa selama proses produksi berlangsung tidak akan terjadi kemacetan yang disebabkan oleh mesin atau fasilitas produksi yang tak berfungsi sebagaimana mestinya.

Menurut Ma'arif\& Tanjung (2003:480) Sasaran dari kegiatan pemeliharaan adalah untuk menjaga kemampuan aktiva tetap dan meminimalkan biaya. Kemampuan 
aktiva tetap harus dipelihara karena aktiva tetap yang sudah "tidak mampu" akan menyebabkan hasil yang "gagal". Output yang cacat akan menyebabkan tambahan biaya karena harus diproses kembali, dampak negatif yang lebih besar adalah berkurangnya kepercayaan konsumen kepada perusahaan akibat produk yang cacat. Tambahan biaya yang timbul akan menyebabkan biaya produksi membengkak, yang pada akhirnya harga produk akan menjadi semakin tinggi. Sebaliknya pemeliharaan yang baik akan menciptakan keterandalan. Keterandalan akan menciptakan efisiensi dan efisiensi akan menciptakan keuntungan (laba).

Menurut Henry dalam Kustatik (2009:2) setiap perusahaan akan berusaha mencapai laba yang optimal. Secara umum apabila biaya yang dikeluarkan semakin besar maka laba yang diperoleh akan semakin kecil, sebaliknya apabila biaya semakin rendah dan pendapatan semakin besar maka laba yang diperoleh akan semakin besar.

Nikmat (2000:15) bahwa perusahaan kadang melakukan pengurangan biaya tanpa memperhatikan akibat yang dapat ditimbulkannya. Sebagai contoh biaya pemeliharaan yang dikurangi karena terlalu besar. Padahal dengan besarnya biaya tersebut maka akan mendapatkan manfaat yang besar pula seperti terjaminnya kelancaran produksi. Meskipun demikian pengeluaran biaya ini harus tetap diawasi dan diselaraskan dengan tujuan yang ingin dicapai oleh perusahaan.

Menurut Faisal (2008:46) biaya pemeliharaan aktiva tetap memegang peranan yang penting, jika biaya pemeliharaan aktiva tetap bertambah maka akan menyebabkan kenaikan terhadap pendapatan. Dari pendapat tersebut dapat disimpulkan bahwa apabila perusahaan melakukan pemeliharaan maka aktiva tetap akan dapat dipergunakan secara efektif dan proses produksi akan berjalan lancar, sehingga dengan lancarnya proses produksi maka penjualan dapat meningkat, dari peningkatan penjualan inilah dapat meningkatkan laba yang diperoleh perusahaan.

PT. Cipta Beton Sinar Perkasa adalah salah satu perusahaan yang 
bergerak dalam bidang produksi
campuran beton jadi, jasa kontraktor,
dan developer. Perusahaan tersebut
memiliki banyak aktiva tetap seperti
alat-alat berat untuk produksi dan
kendaraan yang memerlukan
pemeliharaan
berkesinambungan agar kondisi
aktiva tetap tersebut berada dalam

Tabel 1.

Data biaya pemeliharaan aktiva tetap dan laba PT. Cipta Beton Sinar Perkasa

\begin{tabular}{ccc} 
Tahun & Biaya Pemeliharaan Aktiva Tetap & Laba \\
\hline 2011 & $\operatorname{Rp} 46.251 .800$ & $\operatorname{Rp~} 88.098 .350$ \\
2012 & $\operatorname{Rp} 54.755 .400$ & $\operatorname{Rp~92.834.900~}$ \\
2013 & $\operatorname{Rp} 74.336 .800$ & $\mathrm{Rp} \mathrm{117.825.400}$ \\
\end{tabular}

kondisi baik yang pada akhirnya produksi perusahaan bisa tetap berjalan dengan lancar.

$$
\text { Adapun data biaya }
$$

pemeliharaan aktiva tetap dan laba PT. Cipta Beton Sinar Perkasa tahun 2011 - 2013, dapat dilihat pada tabel 1 berikut ini :

Sumber: PT. Cipta Beton Sinar Perkasa

Tabel 1, menunjukkan bahwa laba perusahaan meningkat setiap tahunnya. Pada tahun 2011, pengeluaran biaya pemeliharaan aktiva tetap sebesar Rp 46.251.800,- dan laba yang diperoleh sebesar Rp 88.098.350,- Selanjutnya, pada tahun 2012 pengeluaran biaya pemeliharaan aktiva tetap dan laba meningkat masing-masing $\mathrm{Rp}$ 54.755.400,-dan Rp 92.834.900,-Adapun kenaikan biaya dari tahun 2011 ke tahun 2012 sebesar Rp 8.503.600 $(18,38 \%)$ dan laba Rp 4.736 .550
(5,37\%). Tahun 2013 biaya pemeliharaan aktiva tetap meningkat menjadi $\mathrm{Rp}$ 74.336.800,- dan laba yang diperoleh $\mathrm{Rp}$ 117.825.400,-. Adapun kenaikan biaya dari tahun 2012 ke tahun 2013 sebesar Rp19.581.400 (35,76 \%) dan laba Rp $24.990 .500(26,91 \%)$. Data tersebut menunjukkan bahwa peningkatan biaya pemeliharaan aktiva tetap di ikuti pula oleh peningkatan laba yang diperoleh perusahaan.

Berdasarkan uraian di atas, yang menjadi tujuan dalam penelitian ini adalah 
untuk mengetahui besarnya pengaruh biaya pemeliharaan aktiva tetap terhadap laba pada PT. Cipta Beton Sinar Perkasa di Kota Makassar.

\section{METODE PENELITIAN}

\section{A. Variabel Penelitian}

Berdasarkan topik penelitian yang akan dibahas maka variabel yang digunakan dalam penelitian ini yaitu :

1. Biaya pemeliharaan aktiva tetap PT. Cipta Beton Sinar Perkasa sebagai variabel bebas yang diberi simbol $(\mathrm{X})$

2. Laba PT. Cipta Beton Sinar Perkasa sebagai variabel terikat yang diberi simbol (Y)

\section{B. Populasi dan Sampel}

a. Populasi

Menurut Sugiyono (2008:61) "populasi adalah wilayah generalisasi yang terdiri atas obyek/subyek yang mempunyai kualitas dan karakteristik tertentu yang ditetapkan oleh peneliti untuk dipelajari dan kemudian ditarik kesimpulannya". Adapun yang menjadi populasi dalam penelitian ini adalah laporan keuangan dalam bentuk laporan laba/rugi, laporan harga pokok dan neraca yang diterbitkan oleh PT. Cipta Beton Sinar Perkasa di Kota Makassar.

b. Sampel
Menurut Sugiyono

(2008:62) "sampel adalah bagian dari jumlah dan karakteristik yang dimiliki oleh populasi tersebut". Adapun data dalam penelitian ini bersifat time series. Sampel yang diambil berasal dari data laporan keuangan khususnya laba/rugi, laporan harga pokok dan neraca selama lima tahun terakhir yaitu tahun 2004-2008 pada PT. Cipta Beton Sinar Perkasa di Kota Makassar.

\section{Teknik Pengumpulan Data}

Dalam penelitian ini ada beberapa teknik yang diperlukan dalam pengumpulan data yaitu :

a. Dokumentasi, yakni mengumpulkan dokumen-dokumen seperti laporan keuangan (laba/rugi, laporan harga pokok dan neraca) serta dokumendokumen lain yang sesuai dengan yang dibutuhkan.

b. Wawancara, yakni dengan melakukan tanya jawab dengan pimpinan PT. Cipta Beton Sinar Perkasa di Kota Makassar

c. Observasi, yakni pengamatan secara langsung keadaan perusahaan

\section{Teknik Analisis data}

Analisis yang digunakan yaitu :

a. Analisis Regresi Linear Sederhana 
Untuk mengetahui bentuk hubungan variabel yang diteliti yaitu variabel bebas (X) dan variabel terikat $(\mathrm{Y})$ digunakan rumus Sugiyono (2008:261)

$\hat{\mathrm{Y}}=\mathrm{a}+\mathrm{bX}$

Dimana : $\hat{Y}=$ Laba $(\mathrm{Rp})$

$\mathrm{X}=$ Biaya pemeliharaan aktiva tetap $(\mathrm{Rp})$

$\mathrm{a}=$ Konstanta

$\mathrm{b}=$ Koefisien Regresi

\section{HASIL PENELITIAN DAN PEMBAHASAN}

\section{A. Hasil Penelitian}

\section{Gambaran Umum PT. Cipta Beton} Sinar Perkasa

\section{a. Sejarah Singkat}

PT. Cipta Beton Sinar Perkasa (CBSP) merupakan salah satu perusahaan yang bergerak dibidang produksi beton jadi, kontraktor dan developer yang berkantor dimakassar. PT. Cipta Beton Sinar Perkasa didirikan pada tanggal 24 April 1995 dengan akte notaries nomor 97 oleh Sri Hartini Widjaya SH yang kemudian dirubah pertama dengan akte notaris nomor 98 tanggal 23 November 1995. Perubahan kedua akte notaries nomor 96 tanggal 23 Februari 1996. Perubahan-perubahan ini berarti bahwa ada usaha agar perusahaan dapat berkembang pada jalan yang sehat sebagai upaya pencapaian tujuan perusahaan.

Adapun maksud dan tujuan pendirian perusahaan ini adalah untuk melakukan usaha dibidang ekonomi, pembangunan dan jasa dalam arti yang seluas-luasnya. Berbagai usaha yang telah dilakukan antara lain :

1. Melakukan produksi campuran beton jadi

2. Melaksanakan pembangunan, baik yang berupa bangunan sipil gedunggedung, jalan-jalan dan lain-lain.

Perusahaan ini pada awal kegiatannya bergerak dalam bidang pabrik campuran beton jadi. Akan tetapi selaras dengan perkembangan zaman dan peningkatan sarana dan prasarana serta perkembangan tenaga (Karyawan) dalam waktu yang relatif singkat, perusahaan ini memperluas usahanya dalam bidang konstruksi bangunan sipil, pembangunan gedung-gedung, jalan dan lain-lain. Dengan adanya kegiatan usaha tersebut, PT. Cipta Beton Sinar Perkasa mendapat kepercayaan dari Pemerintah Daerah Sulawesi Selatan untuk mengerjakan pembangunan gedung-gedung pemerintah. Adapun alat-alat berat yang 
dimiliki perusahaan pada awal kegiatan usahanya yaitu :

1. Dump Truck

2. Excavator

3. Buldoser

4. Loader

5. Concrete Pump

6. Ready Mixed

Dengan fasilitas yang dimiliki oleh PT. Cipta Beton Sinar Perkasa yaitu pabrik campuran beton jadi perusahaan ini melayani kebututuhan akan beton di daerah Makassar dan 5 daerah sekitarnya. Pada awal tahun 1995 PT. Cipta Beton Sinar Perkasa memperluas usahanya dalam bidang kontrktor dan developer. Dengan perluasan usaha tersebut perusahaan ini berupaya untuk mengerjakan proyek-proyek yang telah diberikan oleh pemerintah dan swasta dengan baik dan tepat pada waktunya.

Dengan melihat prospek yang cukup baik untuk pengembangan usaha khususnya pada produksi campuran beton jadi maka pada tahun-tahun berikutnya pihak manajemen perusahaan berhasil menambah mesin-mesin pabrik campuran beton jadi sebanyak 1 unit, alatalat berat Concret Pump sebanyak 2 unit, Ready Mixer sebanyak 3 unit. Dengan adanya penambahan sarana dan prasarana tersebut dimaksudkan untuk meningkatkan produksi serta pelayanan akan permintaan konsumen terhadap campuran beton jadi.

Perkembangan atau kegiatan yang telah dicapai oleh PT. Cipta Beton Sinar Perkasa selama ini disamping melakukan produksi campuran beton jadi adalah :

1. Pembangunan ruko Jeneberang Permai di Kabupaten Gowa

2. Pembangunan jalan didaerah bili-bili di Kabupaten Gowa

3. Pembangunan irigasi di Kabupaten Sidrap

4. Pembangunan kantor PT. IKI di Makassar dan lain-lain.

\section{b. Visi Misi Perusahaan}

Adapun yang menjadi visi misi perusahaan adalah : unggul dalam pelayanan dan pembuatan beton jadi, menjadi salah satu bagian dalam pembangunan, mengembangkan sumber daya manusia yang dimilikinya, memberikan kepuasan yang maksimal kepada konsumen, dan meningkatkan kesejahteraan karyawan.

\section{c. Cara Memproduksi Beton Jadi dan Alat-Alat Yang Digunakan}

Adapun cara produksi beton dapat digambarkan sebagai berikut : 


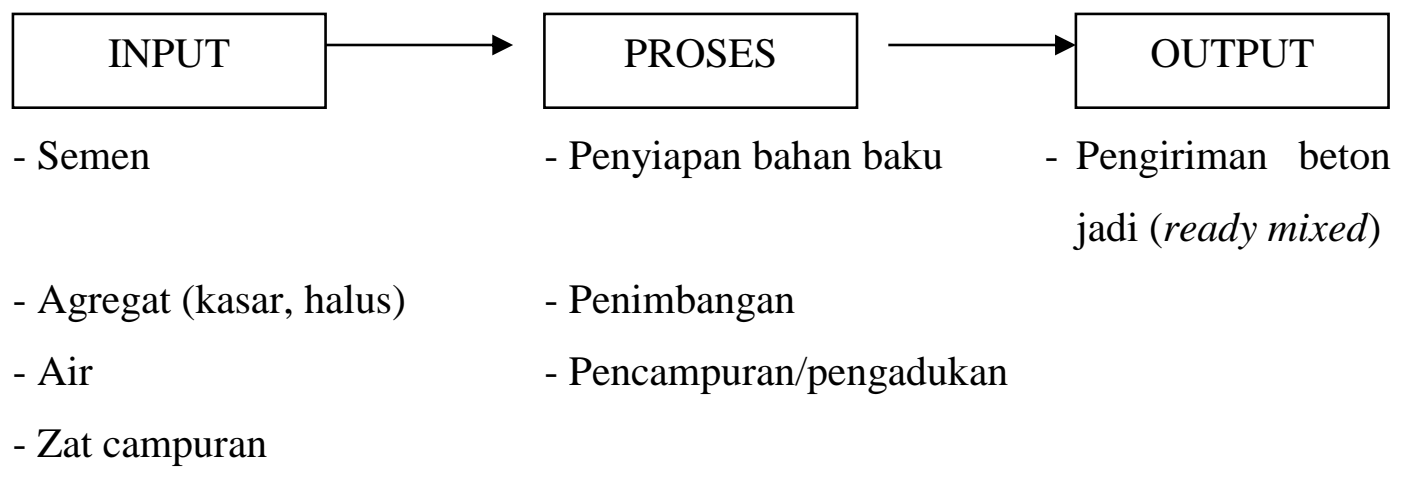

Material atau bahan-bahan untuk

d. Zat campuran yang digunakan seperti pembuatan beton harus tersedia cukup dan perlu dilakukan pengecekan baik kualitas maupun kuantitasnya. Bahanbahan ini terdiri atas :

fosroc yang bertujuan untuk mengawetkan beton.

Secara umum peralatan yang

a. Semen, semen yang digunakan dalam pembuatan beton haruslah semen yang berkualitas baik. Pada PT. Cipta Beton Sinar Perkasa di Kota Makassar ini menggunakan semen tonasa dan semen bosowa.

$b$

b. Agregat, terdiri atas agregat kasar seperti kerikil (chipping dan split) sedangkan agregat halus yaitu pasir. Untuk pengecekan kualitas dilakukan secara visual dengan memperhatikan kekasaran, warna, banyaknya kotoran ataupun sampah.

\section{Jumlah Biaya Pemeliharaan Aktiva Tetap PT. Cipta Beton Sinar Perkasa} bersih dan terhindar dari pengaruh pencemaran sebab dapat mempengaruh kekuatan beton.

\section{Berbagai jenis kegiatan} pemeliharaan aktiva tetap dilakukan oleh PT. Cipta Beton Sinar Perkasa di Kota Makassar untuk menjaga agar aktiva tetap yang dimiliki perusahaan 
selalu dalam kondisi yang baik. Dari kegiatan pemeliharaan yang dilakukan ini memunculkan satu pos biaya yang disebut dengan biaya pemeliharaan aktiva tetap. Adapun jenis-jenis biaya overhead yang ada pada PT. Cipta Beton Sinar Perkasa terdiri atas : biaya pemeliharaan alat, biaya bahan bakar, biaya mobilisasi, biaya asuransi, biaya keamanan, spare part, biaya konsumsi, biaya listrik, biaya telepon, biaya pengobatan dan biaya-biaya lain. Secara umum Biaya pemeliharaan aktiva tetap (alat) menempati posisi terbesar ke enam dari biaya-biaya overhead yang ada. Besarnya persentase biaya overhead adalah : biaya pemeliharaan alat $(5,34 \%)$, biaya bahan bakar (26,69\%), biaya mobilisasi $(8,69 \%)$, biaya asuransi $(3,01 \%)$, biaya keamanan $(1,16 \%)$, spare part $(24,51 \%)$, biaya konsumsi $(7,71 \%)$, biaya listrik $(2,82 \%)$, biaya telepon $(1 \%)$, biaya pengobatan $(0,54 \%)$ dan biaya-biaya lain (18,57\%). (data selengkapnya dapat dilihat pada lampiran).

Biaya pemeliharaan aktiva tetap pada PT. Cipta Beton Sinar Perkasa di Kota Makassar ini terdiri atas biaya pemeliharaan gedung/bangunan, biaya pemeliharaan kendaraan, biaya pemeliharaan dan reparasi mesin-mesin pabrik. Namun yang akan penulis analisis disini adalah biaya pemeliharaan mesin-mesin/alat berat pabrik yang merupakan salah satu komponen biaya overhead pada laporan harga pokok. Pihak manajemen perusahaan berusaha mengoptimalkan kegiatan operasional dalam upaya menjaga kepuasan konsumen, peningkatan pendapatan dan perolehan laba yang maksimal. Pemeliharaan dan perbaikan di PT. Cipta Beton Sinar Perkasa di Kota Makassar dilakukan oleh pihak PT. Cipta Beton Sinar Perkasa itu sendiri. Aktivitas pemeliharaan diketahui oleh bagian tertentu yakni bagian peralatan/maintenance dalam hal ini ditangani oleh tenaga mekanik. Pemeliharaan yang melibatkan pihak luar tidak dilakukan selama bagian mekanik masih mampu untuk sepenuhnya melakukan aktivitas pemeliharaan. Akan tetapi jika pihak perusahaan sudah tidak sanggup melakukan pemeliharaan maka akan melibatkan unsur di luar perusahaan untuk perbaikan aktiva tetap yang mengalami kerusakan parah. 
Proses aktivitas pemeliharaan di PT. Cipta Beton Sinar Perkasa diawali dengan permintaan dari pemakai/operator kepada bagian yang menangani pemeliharaan terhadap objek tersebut secara lisan. Setelah diterima permintaan lisan dari pemakai/operator maka bagian mekanik memeriksa aktiva tetap tersebut. Jika ternyata terjadi kerusakan pada aktiva tetap maka mekanik akan melaporkan kepada bagian maintenance setelah itu dilanjutkan dengan permintaan tertulis dari bagian maintenance yang ditujukan kepada Direktur Utama PT. Cipta Beton Sinar Perkasa. Bagian maintenance bersama dengan mekanik akan melakukan aktivitas pemeliharaan dan perbaikan apabila permohonan yang diminta oleh pemakai telah disetujui oleh Direktur Utama PT. Cipta Beton Sinar Perkasa. Bagian maintenance biasanya membeli suku cadang dan alat-alat keperluan pemeliharaan pada PT. Andalas Teknik di Kota Makassar. Selanjutnya keseluruhan biaya yang dikeluarkan untuk memelihara aktiva tetap perusahaan digabungkan kedalam satu rekening yaitu biaya pemeliharaan aktiva tetap.
Terkait dengan biaya pemeliharaan ini pihak perusahan lebih memilih untuk memiliki aktiva tetap yang digunakan dalam proses produksi dari pada melakukan penyewaan aktiva/mesin-mesin milik perusahaan lain dengan pertimbangan bahwa jika melakukan penyewaan mesin maka biaya sewa lebih tinggi dari pada biaya pemeliharaan yang dikeluarkan.

3. Jumlah Laba PT. Cipta Beton Sinar Perkasa

$\begin{aligned} \text { Laba } & \text { adalah selisih antara } \\ \text { pendapatan } & \text { yang diperoleh dengan }\end{aligned}$ biaya yang digunakan sehubungan dengan kegiatan usaha. Laba merupakan tujuan yang ingin dicapai dalam jangka pendek sehingga kontinuitas usaha tetap berjalan. Oleh karena itu, faktor-faktor yang mempengaruhi besar kecilnya laba perlu mendapat perhatian khusus oleh PT. Cipta Beton Sinar Perkasa di Kota Makassar.

Perkembangan laba yang diperoleh PT. Cipta Beton Sinar Perkasa di Kota Makassar, terlihat bahwa laba yang diperoleh PT. Cipta Beton Sinar Perkasa di Kota Makassar berfluktuasi setiap tahun. Pada tahun 
2012 laba PT. Cipta Beton Sinar Perkasa di Kota Makassar sebesar Rp 195.275.800,-. Tahun 2013 laba PT. Cipta Beton Sinar Perkasa mengalami peningkatan hingga menjadi $\mathrm{Rp}$ 215.752.500,- atau peningkatannya sebesar Rp 20.476.700,- (10,49\%) dari tahun sebelumnya. Kemudian pada tahun 2014, laba PT. Cipta Beton Sinar Perkasa mengalami penurunan dari tahun sebelumnya 41,28\% atau sebesar Rp 89.053.300,-. Hal ini disebabkan oleh menurunnya aktivitas/penjualan dan biaya pemeliharaan aktiva tetap perusahaan.
4. Pengaruh Biaya Pemeliharaan Aktiva Tetap Terhadap Laba Pada PT. Cipta Beton Sinar Perkasa di Kota Makassar

Untuk mengetahui pengaruh biaya pemeliharaan aktiva tetap terhadap laba pada PT. Cipta Beton Sinar Perkasa di Kota Makassar maka dilakukan analisis regresi linear sederhana dengan program komputer SPSS (Statistic Product and Service Solution) yang dapat dilihat pada tabel berikut ini :

Tabel 2. Analisis Regresi Linear Sederhana

Coefficients $^{\mathrm{a}}$

\begin{tabular}{|c|c|c|c|c|c|}
\hline \multirow[b]{2}{*}{ Model } & \multicolumn{2}{|c|}{ Unstandardized Coefficients } & \multirow{2}{*}{\begin{tabular}{|c|c}
$\begin{array}{c}\text { Standardize } \\
\mathrm{d} \\
\text { Coefficients }\end{array}$ \\
Beta
\end{tabular}} & \multirow[b]{2}{*}{$\mathrm{t}$} & \multirow[b]{2}{*}{ Sig. } \\
\hline & B & Std. Error & & & \\
\hline 1 (Constant) & 68004204.175 & 29379522.148 & & 2.315 & .104 \\
\hline Biaya & & & & & \\
\hline $\begin{array}{l}\text { Pemeliharaan } \\
\text { Aktiva Tetap }\end{array}$ & -1.419 & .435 & -.883 & -3.265 & .047 \\
\hline
\end{tabular}

a. Dependent

Variable: Laba

Dari data diatas maka dapat dibuat persamaan regresi linearnya dimana nilai a yang diperoleh sebesar 68.004.204,18 dan nilai $b$ yang diperoleh sebesar - 1,419 sehingga jika dimasukkan kedalam persamaan akan menjadi : $\hat{\mathrm{Y}}=$ 68.004.204,18 - 1,419 X.

Persamaan tersebut berarti bahwa nilai konstanta 68.004.204,18 
adalah besarnya laba (Y) yang dapat dicapai tanpa memperhatikan besar kecilnya biaya pemeliharaan aktiva tetap. Adapun nilai koefisien regresi sebesar - 1,419 berarti apabila biaya pemeliharaan aktiva tetap bertambah sebesar Rp 1,- maka nilai laba pada PT. Cipta Beton Sinar Perkasa di Kota Makassar akan berkurang sebesar Rp $1,419,-$

\section{B. Pembahasan Hasil Penelitian}

1. Analisis Biaya Pemeliharaan Aktiva Tetap pada PT. Cipta Beton Sinar Perkasa di Kota Makassar

Biaya pemeliharaan aktiva tetap dari tahun ke tahun mengalami perubahan kadang naik kadang turun. Hal ini disebabkan karena metode penjualan yang dilakukan oleh perusahaan adalah metode pesanan. Jadi, perusahaan melakukan produksi sesuai dengan banyaknya pesanan dari konsumen. Makin sering mesinmesin produksi berproduksi atau alat berat digunakan maka pemeliharaan aktiva tetap juga akan semakin bertambah karena pemeliharaan ini juga selalu rutin dilakukan hal ini juga dipengaruhi oleh aktiva tetap yang semakin tua umurnya. Dengan adanya peningkatan kegiatan pemeliharaan maka biaya pemeliharaan juga akan semakin besar dan oleh karena itu akan mendapatkan manfaat yang besar pula seperti terjaminnya kelancaran produksi sebab hal-hal yang dapat mengakibatkan kerusakan telah diminimalisir, dengan lancarnya proses produksi maka penjualan dapat meningkat, dari peningkatan penjualan inilah akan berdampak positif terhadap laba yang diperoleh perusahaan. Tetapi, biaya yang terlalu besar dari yang dibutuhkan juga dapat menyebabkan laba menjadi lebih kecil.

\section{Analisis Laba pada PT. Cipta Beton Sinar Perkasa di Kota Makassar}

\begin{tabular}{ccc}
\multicolumn{2}{c}{ Peningkatan laba yang } \\
diperoleh PT. Cipta Beton Sinar
\end{tabular} Perkasa disebabkan adanya peningkatan penjualan perusahaan dan pemeliharaan aktiva hal ini dapat tercermin dari laporan laba rugi perusahaan. Selain itu biaya-biaya usaha yang dikeluarkan oleh perusahaan lebih kecil dari pada pendapatan yang berasal dari penjualan barang sehingga terdapat selisih lebih (laba). Oleh sebab itu biaya pemeliharaan aktiva tetap 
memegang peranan yang penting dalam menjaga kelancaran proses produksi dan peningkatan penjualan yang selanjutnya dari penjualan akan berpengaruh terhadap perolehan laba pada periode tertentu.

\section{Analisis Pengaruh Pengaruh} Biaya Pemeliharaan Aktiva Tetap Terhadap Laba Pada PT. Cipta Beton Sinar Perkasa di Kota Makassar

Berdasarkan hasil pengelolaan komputer diperoleh hasil persamaan regresi linear sederhana sebagai berikut: $\hat{Y}=68.004 .204,18$ 1,419 X. Persamaan tersebut berarti bahwa nilai konstanta 68.004.204,18 adalah besarnya laba (Y) yang dapat dicapai tanpa memperhatikan besar kecilnya biaya pemeliharaan aktiva tetap. Adapun nilai koefisien regresi sebesar 1,419 berarti apabila biaya pemeliharaan aktiva tetap bertambah sebesar Rp 1,- maka nilai laba pada PT. Cipta Beton Sinar Perkasa di Kota Makassar akan berkurang sebesar Rp1,419,- dengan asumsi penjualan dan produksi tetap.

Berdasarkan hasil analisis di atas, maka dapat disimpulkan bahwa biaya pemeliharaan aktiva tetap berpengaruh negatif signifikan terhadap laba yang diperoleh PT. Cipta Beton Sinar Perkasa di Kota Makassar. Oleh sebab itu pihak perusahaan perlu mengoptimalkan kegiatan operasionalnya dan memperhatikan biaya pemeliharaannya. Ketika aktiva selalu terpelihara dan terjaga dengan baik kondisinya maka aktiva dapat dipergunakan secara efektif untuk produksi sesuai dengan rencana dan tidak mengalami kerusakan selama dipergunakan atau sebelum jangka waktu tertentu yang direncanakan tercapai. Sehingga proses produksi dapat berjalan lancar, dengan lancarnya proses produksi ini maka penjualan dapat meningkat dan laba pun pada akhirnya dapat meningkat. Namun besarnya biaya pemeliharaan ini perlu tetap diawasi agar tidak melebihi kebutuhan perusahaan. Sebab biaya yang terlalu besar melebihi kebutuhan dapat menyebabkan perolehan laba menjadi lebih kecil. Beberapa hal penting untuk diperhatikan dalam pencapaian laba yang maksimal adalah adalah penjualan, volume produksi dan biaya. 


\section{KESIMPULAN DAN SARAN}

\section{Kesimpulan}

Berdasarkan uraian pada babbab sebelumnya dan hasil penelitian yang telah dilakukan maka penulis dapat menarik kesimpulan yaitu Hasil analisis regresi linear sederhana menunjukkan bahwa nilai konstanta 68.004.204,18 adalah besarnya laba (Y) yang dapat dicapai tanpa memperhatikan besar kecilnya biaya pemeliharaan aktiva tetap. Adapun nilai koefisien regresi berarti apabila biaya pemeliharaan aktiva tetap bertambah sebesar Rp 1,- maka nilai laba pada PT. Cipta Beton Sinar Perkasa di Kota Makassar akan menurun sebesar Rp 1,419,-. Dengan demikian biaya pemeliharaan aktiva tetap berpengaruh negatif dan signifikan terhadap laba yang diperoleh PT. Cipta Beton Sinar Perkasadi Kota Makassar.

\section{Saran}

Sehubungan dengan hasil penelitian diatas, maka penulis menyampaikan saran-saran sebagai berikut :

1. Diharapkan pada PT. Cipta Beton Sinar Perkasa di Kota Makassar agar mempertahankan bahkan meningkatkan kegiatan pemeliharaannya karena aktiva yang tidak terpelihara dengan baik akan menyebabkan kerusakan yang lebih cepat.

2. Untuk penelitian berikutnya disarankan agar meneliti variabel lain yang berkaitan dengan biaya pemeliharaan aktiva tetap selain laba.

\section{DAFTAR PUSTAKA}

Arikunto, Suharsimi. 2000. Manajemen Penelitian. Jakarta: Rineka Cipta

Assauri, Sofjan. 2008. Manajemen Produksi dan Operasi. Jakarta: BPFE UI

Baridwan, Zaki. 2000. Intermediate Accounting. Yogyakarta : BPFE

Belkaoui. 2006. Accounting Theory. Jakarta: Salemba Empat.

Carter, William \& Milton F Usry. 2004. Akuntansi Biaya. Jakarta : Salemba Empat

Condro, Ari. 2005. Relevansi ModelModel Penilaian dan Pengukuran Laba Akuntansi Konvensional Terhadap Akuntansi Syariah, (online) (http/www.google.com, Diakses 06 April 2008)

Faisal, Fontana. 2008. Peranan Biaya Pemeliharaan dan Perbaikan 
Dalam Meningkatkan

Pendapatan Operasional

Rumah Sakit. Skripsi. Universitas Widyatama.

Handoko, Hani. 2000. Dasar-Dasar Manajemen Produksi \& Operasi. Yogyakarta : BPFE

Horngren, T. Charles.1998. Pengantar Akuntansi Manajemen. Jakarta : Erlangga

Garrison, Ray.dkk. 2006. Managerial Accounting. Jakarta : Salemba Empat

Kustatik, Henik. 2009. Analisi Break Even dan Manfaatnya Sebagai Perencanaan Laba Pada Perusahaan Plastik Tri Tan Lestari di Telukan Sukoharjo. Skripsi. Universitas Muhammadiyah Surakarta.

Ma'arif, Syamsul \& Hendri Tanjung. 2003. Manajemen Operasi. Jakarta: Grasindo

Mulyadi. 2001. Akuntansi Manajemen. Jakarta : Salemba Empat -. 2002. Akuntansi Biaya. Yogyakarta : Aditya Media

Muqodim. 2005. Teori Akuntansi. Yogyakarta : Ekonisia

Nikmat, Yaumil. 20000. Analisis Rentabilitas Untuk Mengukur Kinerja Perusahaan. (online) (http/www.guruvalah.com, Diakses 31 Januari 2010)

Rayburn, Gayle. L. 1999. Akuntansi Biaya. Jakarta : Erlangga
Sigit, Soehardi. 2001. Metodologi Penelitian. Yogyakarta: BPFE UST

Simamora, Henry.2003. Akuntansi Berbasis Pengambilan Keputusan Bisnis. Yogyakarta : UPP AMP YKPN

Smith, Jay. 1997. Akuntansi Intermediate. Jakarta: Erlangga.

Soemarso. 2004. Akuntansi Suatu Pengantar. Jakarta : Salemba Empat

Suwardjono. 2008. Teori Akuntansi. Yogyakarta : BPFE

Soerwartoyo, Lumbantorum. 2004. Ensiklopedia Ekonomi Bisnis \& Manajemen. Semarang : Delta Pamungkas

Sugiyono. 2008. Statistika Untuk Penelitian. Bandung : Alfabeta

Supriyono. 1999. Akuntansi Biaya, Pengumpulan Biaya dan Penentuan Harga Pokok. Yogyakarta: BPFE.

Tampubolon, Manahan. 2003. Manajemen Operasional. Jakarta : Ghalia Indonesia

Prawirosentono, Suyadi. 2007. Manajemen Operasi. Jakarta: Bumi Akasara 